\title{
Urban Settlement Spatial Analysis in Permanent Preservation Area of M'boicy Watershed River, Foz do Iguaçu City in Brazil
}

\author{
Luis Henrique Weiss de Carvalho ${ }^{1 *}$, Sandro Laudares², Matheus Pereira Libório3, \\ Marianna Petrovna Ekel ${ }^{4}$, Renato de Oliveira Marques ${ }^{2}$
}

${ }^{1}$ Geoprocessing, GeoInnovit Soluções Tecnológicas, Foz do Iguaçu, Brazil

${ }^{2}$ Department of Geoghaphy, Pontifical Catholic University of Minas Gerais, Belo Horizonte, Brazil

${ }^{3}$ Department of Distance Learning, Pontifical Catholic University of Minas Gerais, Belo Horizonte, Brazil

${ }^{4}$ Research Support Foundation of Minas Gerais, Belo Horizonte, Brazil

Email: *weiss.luis@gmail.com

How to cite this paper: de Carvalho, L.H.W., Laudares, S., Libório, M.P., Ekel, M.P. and Marques, R. de O. (2016) Urban Settlement Spatial Analysis in Permanent Preservation Area of M'boicy Watershed River, Foz do Iguaçu City in Brazil. International Journal of Geosciences, 7, 1222-1231. http://dx.doi.org/10.4236/ijg.2016.710091

Received: September 22, 2016

Accepted: October 24, 2016

Published: October 27, 2016

Copyright $\odot 2016$ by authors and Scientific Research Publishing Inc. This work is licensed under the Creative Commons Attribution International License (CC BY 4.0).

http://creativecommons.org/licenses/by/4.0/ (c) (i) Open Access

\begin{abstract}
Irregular urban settlement increases environmental impacts, especially when these occupations occur in fragile location, as the environmental preservation areas. In these areas, also defined as Permanent Preservation Area (PPA), the presence of watersheds is common, which is the factor that increases the need of protecting them from anthropic actions. Those actions deteriorate the environment and mainly the watercourses. This research objective is to identify and estimate the environmental risks of M'Boyci watershed River PPA occupied areas by urban population. The risk analysis approach, at this PPA in Foz do Iguaçu City in Brazil, is able to support public interventions in order to reestablish the PPA natural conditions. To reach this goal, it was necessary to use cartographical representation images, generated from digital orthophotos analyzed through free geographical information systems. The overlap and the contrast of geographical data related to preservation in urban areas show that urban occupation reaches almost $40 \%$ of the permanent preservation area. Complementarily, it is evidenced that the development of a risk map identifies PPA areas characterized by a greater concentration of irregular settlement, contributing to the planning process of residents, relocation actions and recovery of degraded areas.
\end{abstract}

\section{Keywords}

Urban Settlement, Permanent Preservation Areas, Environmental Impact, Spatial Analysis, Geographical Information System 


\section{Introduction}

The deranged demographic growth in big cities is, according to [1], very much present in developing countries. In Brazil, due to shantytowns and irregular occupations, [2] discusses that frequent anthropic actions related to the environment enlarge environmental impacts, making them more evident, especially in the structural, geographical and visual sphere of the cities.

Urban growth, lately, is leading to frequent disorganized occupations in Permanent Preservation Area (PPA) on the edges of rivers, as shown by [3] [4] and [5], as occurring in the studied city.

The PPA, according to [5], has the task of fragile environment protection, as river edges, favoring watercourses continuity, but in several recent studies the inefficiency of regulatory agency studies in PPA's advances land occupations control becomes evident.

In this context, this research aims to present a spatial analysis methodology to identify irregular occupation areas, which presents higher risks. In order to achieve the goal, geographical data about the occupation of urban land and environmental zoning data will be used.

The research approaches geotechnology and the geographical quantitative methods for spatial analysis, executed using free geographical information systems to identify the irregular occupations in PPA of M’Boicy River, Foz do Iguaçu. Geotechnology is defined by [6] as a set of integrated technologies to geographical fundamentals with the goal of exploring and divulgating geographical information. Thus, through quantification, the spatial analysis [7] is applied aiming to evidence and describe phenomena, temporal and pattern evolution as well, seeking for data explanation.

\subsection{Definitions and Concepts}

The PPA defined by environmental law in Brazil has its first definitions elaborated in the Brazilian Forest Code, specifically in Decree 23,793/34 from 1934. In the explaining of PPA's ecosystem, [8] exposed that these must contain environmental appearances, socioeconomic and cultural aspects, which are promoting factors for the improvement of human life quality. Besides, the preservation of PPA's is important in managing watersheds and possesses a significant role in maintaining equilibrium in the hydrologic cycles.

In this context, [9] stresses that environmental preservation in watershed areas is not something only present in current days. Watersheds are defined by [10] as regions on which surface runoff in any point will converge to a common outlet called catchment area. A set of land is drained by river affluent which forms water splitters in high places of the relief.

The constitution watersheds heads explained by [11] as a set of brooks originated from water flowing in terrains that, when connecting to different water flows rise in volume and constitute the first rivers. Therefore, a watershed can contain smaller sub-watersheds. To the author, the delimitation of watersheds given by square kilometers, representing sub-watersheds are bigger than $100 \mathrm{~km}^{2}$ and smaller than $700 \mathrm{~km}^{2}$. 
However, [12] affirms that the measurement of a sub-watershed area is given in hectares. Therefore, the watershed as stated by this author would represent an area possessing something in between 20,000 and 30,000 hectares, that is, between 200 and 300 square kilometers.

The watershed is characterized by [13] as a composition of elements. Such as a water divider, soil, formal elements, draining networks, declivity and the hypsometric curve. The water dividers, featured as geological and topographical, connecting in the main section of the water basin and accomplishing the limitation of the draining area. This is one of the characterizing elements of the watershed. According to [13], the watershed soils are stratified by a particular classification, which consists one of the phases in the geomorphological and physiographic study of the watershed.

Watersheds importance, as explained by [14], reveals physical indicators that allow for qualifications of environmental alterations, allowing the study of environmental vulnerability in a drainage basin. According to [15], the drainage network composed by a main course of water and its contributors feature a watershed. The drainage network is bound to the efficacy in the draining process of the watershed area in the peak flow. The declivity of the watershed is relevant for planning actions, for it possesses a function in law enforcement and in the efficiency of human interventions, revealing itself fundamental in water distribution and in surface and subterranean runoff.

The hypsometric curves are identified as the curves established from the connection between areas percentage in declivity areas, represented in a graphic with the objective of revealing the way in which subterranean rocky volume is distributed [16].

Therefore, the inclusion of human activities in PPA areas as a determinant factor in valorization of urban land impact a fragile environment as declared by [5], generating risks to areas with the presence of watersheds, recall [8].

The term "soil usage and occupation" defined by [17] in the light of rulings on density, activity regimen, building control apparels and the soil division that form the urbanistic regimen of cities. The "soil usage and occupation" is, according to [18], a function depending on zoning. The city zoning is an instrument of the master plans that divide the city in areas on which differentiated directives and urban indicators occur. By delimitating areas and defining soil usage, observing the individual needs and characteristics of each place, zoning tries to assure the social and environmental development of the city.

\subsection{Geotechnology and Quantitative Geography}

In the context of technological advances, it's possible to stress the appearing of the term geoprocessing, which, according to [19], originates from the aggregation of the Greek word geo (Earth) with the Latin word "processus" (progress, "walk forward"), meaning, a process capable of bringing progress to Earth. Geoprocessing, explains [20], puts together hardware, software, databases and methodologies, being therefore a technique formed by a technological confluence.

Geotechnology, also known as geoprocessing is, to [21], a set of technologies to col- 
lect, processing, analysis and information offer with geographical reference. Geotechnology involves the Global Positioning System (GPS), Remote Sensing, Digital Image Processing, Digital Cartography, the Database Management Systems and the Geographic Information Systems (GIS), forming a group of techniques bound to treatment of spatial information.

The technical specialties from GIS are, according to [22], a fundamental element of geoprocessing. These systems are an important instrument to aid in planning, management and identifying environmental activities. The usage of geoprocessing has been recurring in environmental analysis and this fact is shown by [23] [24] and, more recently, on the works of [25] and [26]. These works have shown how geographic databases can be managed and accessed by many users (state power, researchers and other institutions) and, through the treatment of spatial information, generate knowledge that contribute to a more rational decision making process. Geoprocessing applied in environmental methodologies as approached by [27] works on thematic mapping, environmental diagnostics, environmental impact assessments, territorial arrangement and zoning.

In a specific way, the usage of geoprocessing tools that aid in managing watersheds isn't a recent approach, as shown by [28] and [29]. However, new techniques applied as shown through terrain elevation data interpolations, extracted from plan altimetry letters, define topographical dividers in [30] works. Therefore, [27] differentiates GIS from other programs given its function to associate and treat data with geographical attributes.

The template is used to format your paper and style the text. All margins, column widths, line spaces, and text fonts are prescribed; please do not alter them. You may note peculiarities. For example, the head margin in this template measures proportionately more than is customary. This measurement and others are deliberate, using specifications that anticipate your paper as one part of the entire journals, and not as an independent document. Please do not revise any of the current designations.

\section{Materials and Methods}

The main goal of this research is a spatial analysis of irregular occupation in environmental preservation area. The work developed through digital map analysis in a GIS named gvSIG. Figure 1 illustrates the steps followed during the research and synthesized through the methodological flow.

The gvSIG software is, according to [31], a geographical information system developed by Generalitat Valenciana, integrant of Spain government. The GvSIG is an open and free code system and, for this reason, it is possible that the same can be modified according to user's needs. Additionally, the System Extremeño de Analisis Territorial, used as spatial analysis processing system, enabled the desired spatial analysis.

\subsection{Study Area}

In this work, the geographical boundaries treated are the city of Foz do Iguaçu, Paraná 


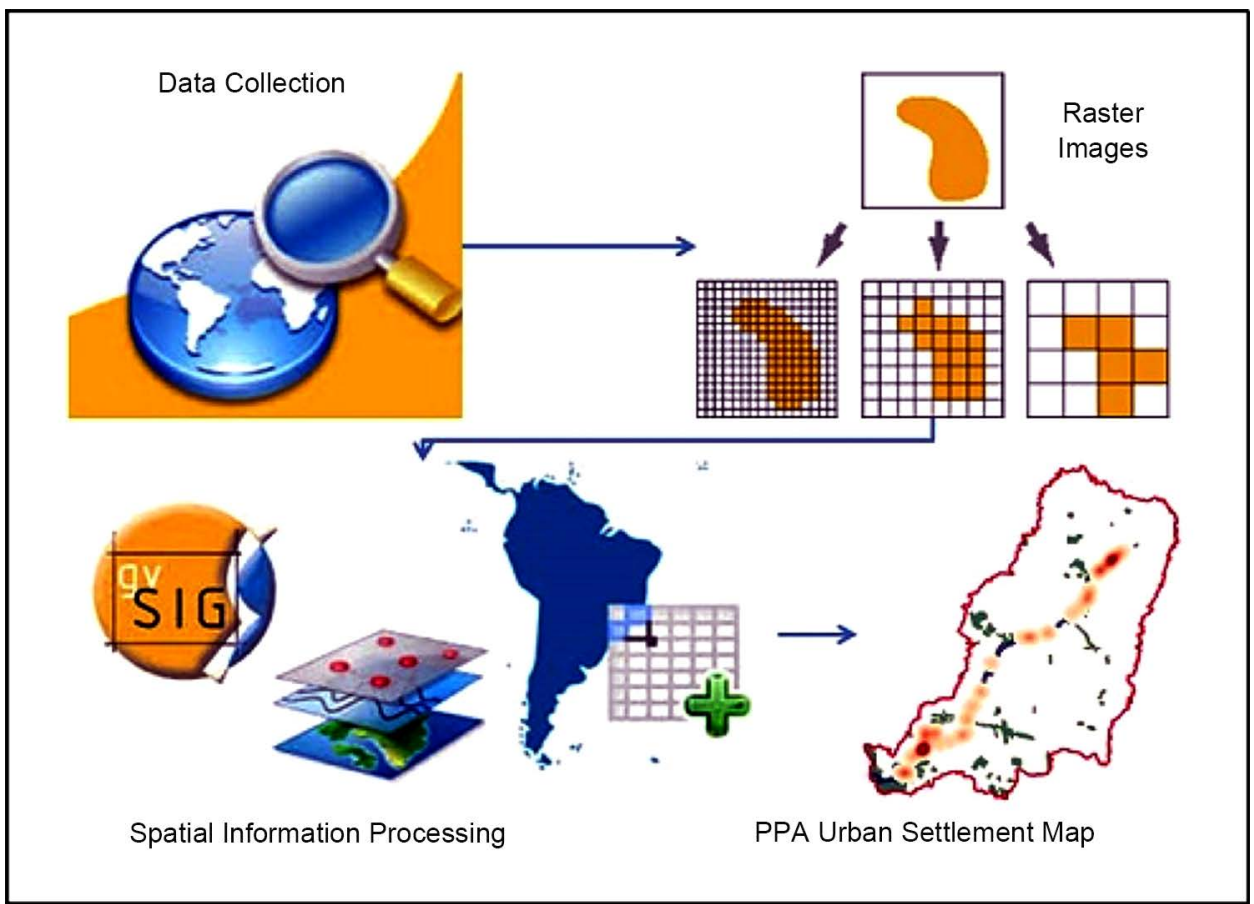

Figure 1. Research activities flow.

State (Figure 2), specifically the watershed area of M'Boyci River. Sendo a escolha desta área motivada pelo fato da PPA se localizar em uma bacia com a presença de uma grande área urbana.

The M'Boyci River is the second hydrographic course in extension considering Foz do Iguaçu city. Its influence in Urban Zoning region is equivalent to $99 \%$ of river's area. The M'Boyci watershed (see Figure 3 ) has its source and mouth disposed in geographic coordinates: $25.508347^{\circ} \mathrm{S}, 54.537786^{\circ} \mathrm{W}$ and $25.554495^{\circ} \mathrm{S}, 54.591291^{\circ} \mathrm{W}$ respectively. According to the spatial analysis performed from census databases and other information available from the cartography of the city municipality, the extension of the study area has 9258 meters in a total area of 25.3 square kilometers, passing through 97 neighborhoods of the city, containing approximately 28.500 residencies and nearly 85,500 inhabitants.

\subsection{Research Steps}

In the first research step, it was collected data from the municipality of Foz do Iguaçu. The main data consists of orthophotos and topographical maps obtained from raster images derived of a $25 \mathrm{~cm}$ per pixel scale, having spatial GSD resolution dated on November 2013 from an aerial survey deferred by the Defense Ministry of Brazil.

In the geographical information treatment step, the collected image data processed in software gvSIG originated the following parts:

1) M'Boyci River watershed influence area delimitation, as it hydrographical network, considering the law in permanent preservation areas which determinates at least 15 meters of the river banks; 


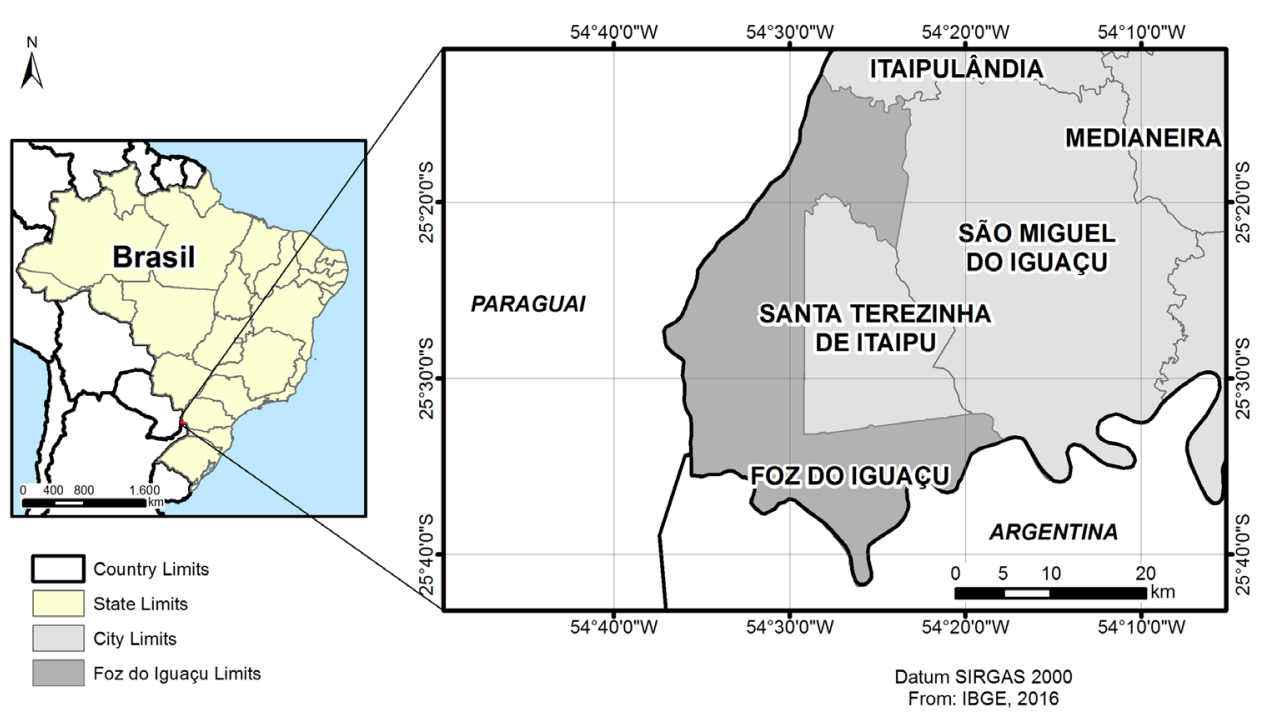

Figure 2. Foz do Iguaçu location map.

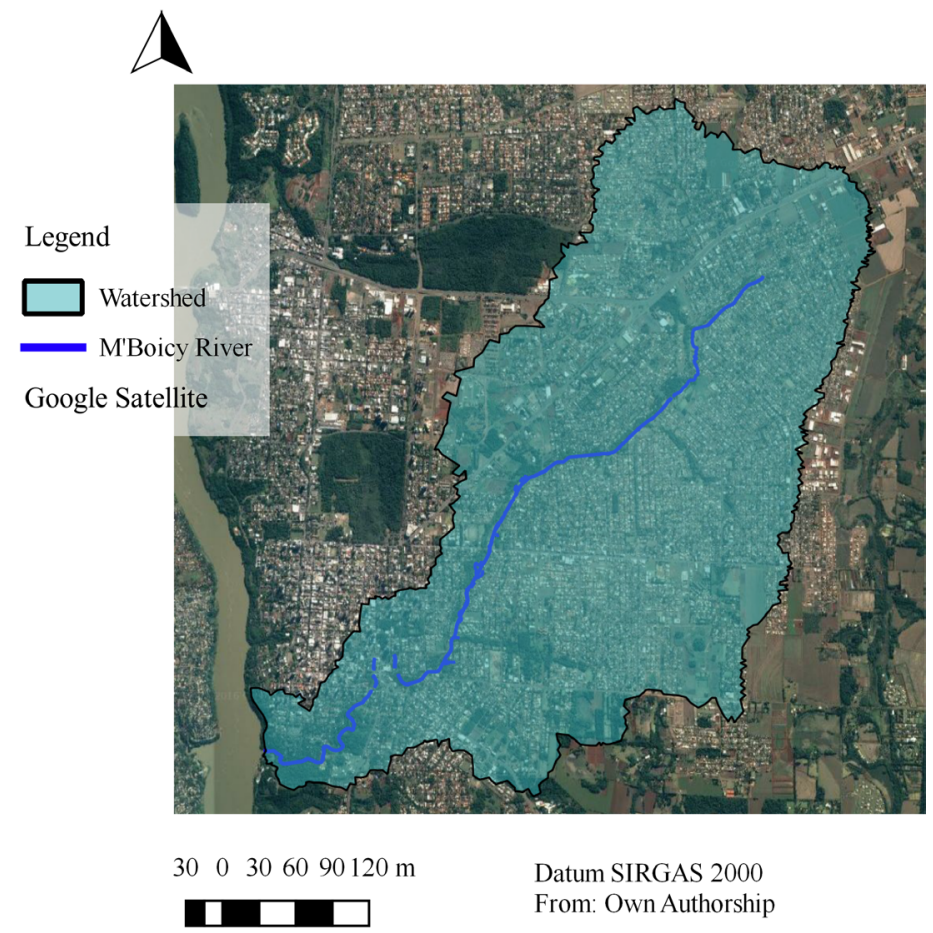

Figure 3. M'Boyci River's location map.

2) Georeferencing work and urban areas characterization surrounding M'Boyci river watershed;

3) Thematic mapping of influence area layers confrontation between watershed and urban areas;

4) Identification of urban areas that occupy PPA delimitation and main affected areas mapping;

5) Analysis and discussions on government actions in environmental and social 
projects and PPA recovery considering risks evaluation.

\section{Results and Discussion}

The obtained results after step (a) M'Boyci River watershed influence area delimitation, demonstrate that only $64.65 \%$ of needed riparian forest for compliance of current legislation referred to M'Boyci River course were identified as permanent preservation areas already existent. Figure 4 presents the M'Boyci River watershed PPA quantification. The total area of PPA obtained through orthophoto analysis was 224,948 square meters, but in original PPA area, the area is 347,955 square meters, demonstrating the results of the reserved areas invasions.

In steps (b; $c$; ), the urban areas surrounding M'Boyci River watershed are georeferenced and confronted to the influent areas of the watershed, making possible the delimitation of urban areas which occupy the PPA. In the land use map related to the main affected areas by urban occupation in M'Boyci River watershed (see Figure 4) it is possible to identify 265 land plots that respect the PPA limits. In these land plots, were identified 71 residences inside the influence banks of the river. Then, it is possible to study residence concentration and riparian forest existent along the river route.

At the end of step (e) government actions in environmental and social projects and PPA recovery in function of risks evaluation, risks evaluation are based on the division in 5 levels of PPA areas, considering the urban concentration inside PPA areas, source of the river proximity and PPA green area density.

Figure 5 presents the map of risks related to permanent preservation area of M'Boyci
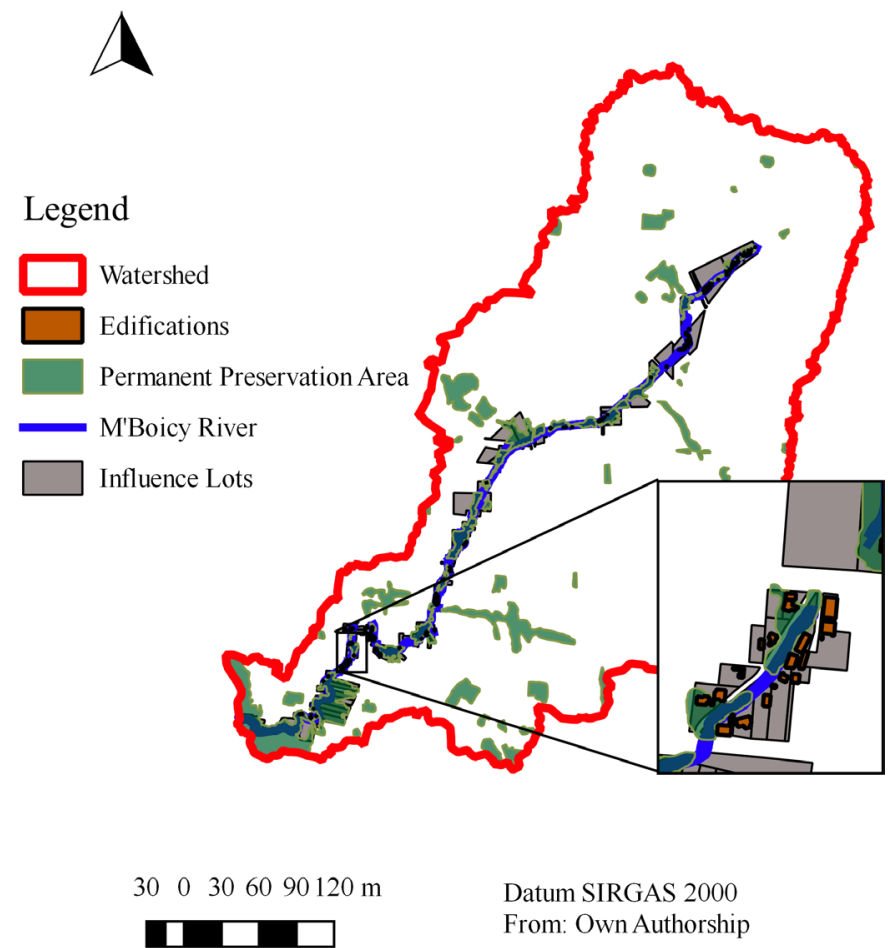

Figure 4. Land use map, lots and edifications. 


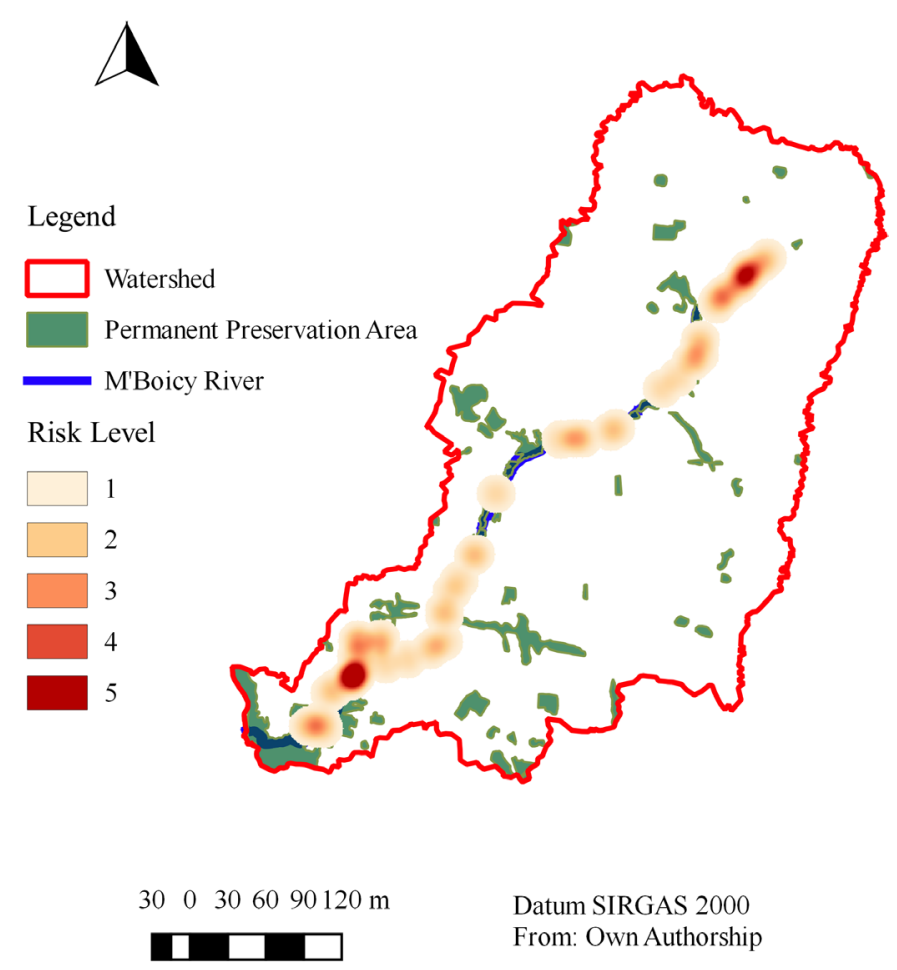

Figure 5. Risk map.

River watershed, obtained from spatial analysis that generated the risk levels identified from the river source in a high concentration area of urban plots and low presence of PPA.

The identification of risk areas allows government actions in the process of planning social and environmental projects for PPAs recovery. These results empower municipal government teams in amplifying public administration knowledge about permanent preservation area and contribute, for example, to the formulation of relocation projects of residents that suffer with floods, diseases and landslides dangers.

\section{Conclusions}

It is possible to conclude that M'Boyci River needs to pass through a fast intervention process, mainly because of the fact that it is a predominantly urban river. Considering this, the existence of residences nearby the river influences the absence of PPA in that part causing not only environmental damage but also social and environmental problems as well as floods, inappropriate pouring of organic matter of sanitation, irregular flow and harmful plumbing to human and hydrographic interaction.

According to [25] in Brazil, from 2009 to 2016 there were over 4000 tax assessments resulting from illegal uses in almost $40 \%$ of federal conservation units in every state of Brazil. The results achieved can be published as an example to other cities in Brazil or even abroad.

Protected areas play an important role in the preservation of fauna and flora, but often there are conflicts, as there are numerous interests of different groups to the use of 
natural resources, whether for economic activities, housing, leisure, among others, criminally or do not. This article achieved its proposed aims in a way that enables city planners to analyze spatially and support decision making in the tax assessments issued to individuals and legal entities with the misuse of permanent preservation areas.

This work aims to help inform and show spatial analysis of permanent protected areas and their location related to other features such as watersheds, biomes and urban settlement within the cities. Future works approaching different technologies and points of view will be able to highlight the limitations and advantages of this research and possible research evolutions. Related researches should be developed in the PPA area in order to study the biodiversity conservation in different biomes and their socialeconomic, cultural, archaeological, historical aspects as well. In Brazil, the consolidation of these areas is slower if compared to other countries. Protected areas have an important role in the preservation, and possible research evolutions include the communication and sharing process through WebGIS and geovisualization approaches enabling greater awareness and transparency.

\section{References}

[1] Martins, R.T.P. and de Sousa Araújo, R. (2014) Benefícios dos Parques Urbanos. Humanas Sociais \& Aplicadas, 4.

[2] Pereira, G. and da Silva, M.N. (2011) Pobreza Urbana e Degradação Ambiental: Algumas Reflexões sobre Curitiba, Brasil. Cuadernos de Vivienda y Urbanismo, 4, 128-141.

[3] Lodo, R.S. and Rosalen, D.L. (2012) Avaliação das Áreas de Preservação Permanente do Rio Mogi Guaçu, no Município de Pitangueiras-SP. Nucleus, 9, 123-130. http://dx.doi.org/10.3738/1982.2278.677

[4] de Araújo, S.M.V.G. (2002) As Áreas de Preservação Permanente e a Questão Urbana.

[5] Ribeiro, C.A.A.S., Lemos, N.D.C.M., de Oliveira Barros, K., Soares, V.P. and Silva, E. (2014) Áreas de Preservação Permanente em Conflito com o Uso e a Ocupação do Solo na Bacia Hidrográfica do Córrego Sertão, Cajuri, Minas Gerais. Revista Agrogeoambiental, 6.

[6] Laudares, S. (2014) Geotecnologia ao Alcance de Todos. Editora Appris, Curitiba

[7] de Abreu, J.F. and Barroso, L.C. (2003) Geografia, Modelos de Análise Espacial e GIS. PUC Minas, Belo Horizonte.

[8] Fisher, 1. and Sá, J. (2007) Estatuto da Cidade e a Resolução Conama n. 369/2006. Seminário sobre o Tratamento de Áreas de Preservação Permanente em Meio Urbano e Restrições Ambientais o Parcelamento do Solo.

[9] Valeri, S.V., et al. (2004) Manejo e Recuperação Florestal: Legislação, Uso da Água e Sistemas Agroflorestais. Funep, Jaboticabal, 142-180.

[10] Barrella, W., Petrere Jr, M., Smith, W.S., Montag, L.D.A., Rodrigues, R.R. and Leitão Filho, H.D.F. (2000) As Relações entre as Matas Ciliares, os Rios e os Peixes. In: Rodrigues, R.R. and Leitão Filho, H.F., Eds., Matas ciliares. Conservação e Recuperação, 2, 187-200.

[11] Faustino, J. (1996) Planificación y Gestión de Manejo de Cuencas. CATIE, Turrialba.

[12] Rocha, C.H.B. (2002) Geoprocessamento: Tecnologia Transdisciplinar. Ed. do Autor.

[13] Tucci, C.E.M. (2007) Hidrologia: Ciências e Aplicação. UFGS.

[14] Teodoro, V.L.I., Teixeira, D., Costa, D.J.L. and Fuller, B.B. (2007) O Conceito de Bacia Hidrográfica e a Importância da Caracterização Morfométrica para o Entendimento da 
Dinâmica Ambiental Local. Revista Uniar, 20, 137-156.

[15] Cardoso, C.A., Dias, H.C.T., Soares, C.P.B. and Martins, S.V. (2006) Caracterização Morfométrica da Bacia Hidrográfica do Rio Debossan, Nova Friburgo, RJ. Revista Árvore, 30, 241-248. http://dx.doi.org/10.1590/S0100-67622006000200011

[16] Christofoletti, A. (1974) Geomorfologia. E. Blucher, São Paulo.

[17] Santos, R.F.D. (2004) Planejamento Ambiental: Teoria Prática. In: Planejamento Ambiental: Teoria e Prática, Oficina de Textos, São Paulo.

[18] da Silva, C.S.G. and de Andrade Aguiar Filho, V. (2013) Contribuições do Zoneamento Ambiental para o Desenvolvimento Sustentável dos Núcleos Urbanos. Jus Navigandi, Teresina 3556.

[19] Moura, A.C.M. (2003) Geoprocessamento na Gestão e Planejamento Urbano. A Autora.

[20] Fitz, P.R. (2008) Geografia Tecnológica. Geoprocessamento sem Complicação. Ed. Oficina de Textos, São Paulo, 19-29.

[21] Rosa, R. (2011) Geotecnologias na Geografia Aplicada. Revista do Departamento de Geografia, 16, 81-90.

[22] Maguire, D.J. (1991) An Overview and Definition of GIS. In: Maguire, D.J., Goodchild, M.F. and Rhind, D.W., Eds., Geographical Information Systems: Principles and Applications, Wiley, Hoboken, Vol. 1, 9-20.

[23] Piroli, E.L., Nicolosi, R.M., Santos, V.R.D. and Melo, C.R.D. (2009) Ferramentas de Geoprocessamento Aplicadas à Análise temporal da Variação do Tamanho das Ilhas do Rio Paraná, na Raia Divisória São Paulo, Mato Grosso do Sul e Paraná. Pesquisa Aplicada \& Agrotecnologia, 1, 38-45.

[24] Gasparini, K.A.C., Lyra, G.B., Francelino, M.R., Delgado, R.C., Oliveira Jr., J.F.D. and Facco, A.G. (2013) Geoprocessing Techniques and Remote Sensing Applied to the Identification of Land Use Conflicts in Seropédica, RJ. Floresta e Ambiente, 20, 296-306.

[25] Mesquita, E.A. and da Cruz, M.L.B. (2016) Geoprocessamento Aplicado ao Mapeamento das Formas de Uso da Terra na Área de Preservação Permanente (APP) da Lagoa do Uruaú-Beberibe/CE. Revista Geonorte, 3, 1509-1518.

[26] Criado, R.C. and Piroli, E.L. (2016) Geoprocessamento como Ferramenta para a Análise do Uso da terra em Bacias Hidrográficas. Revista Geonorte, 3, 1010-1021.

[27] Câmara, G., Davis, C. and Monteiro, A.M.V. (2001) Introdução à Ciência da Geoinformação. INPE.

[28] Weber, E., Duarte, G.F., Frank, M., Hoff, R., Zomer, S., Bassani, E. and Junqueira, I. (1998) Estruturação de Sistemas de Informação Ambiental em Bacias Hidrográficas: o Caso da Bacia Hidrográfica do Rio Caí-RS. GIS Brasil, 98.

[29] Tundisi, J.G. (2006) Novas Perspectivas para a Gestão de Recursos Hídricos. Revista USP, 24-35. http://dx.doi.org/10.11606/issn.2316-9036.v0i70p24-35

[30] Ferreira, R., Moura, M. and Castro, F. (2015) Uso de Plataforma SIG na Caracterização Morfométrica da Bacia Hidrográfica do Rio Pancas-Brasil. Nativa, 3, 210-216. http://dx.doi.org/10.14583/2318-7670.v03n03a11

[31] Anguix, A. (2009) GvSIG: Un Proyecto Global Casos de Éxito. Primera Jornada de Latino América y el Caribe de Usuarios de gvSIG. 
Submit or recommend next manuscript to SCIRP and we will provide best service for you:

Accepting pre-submission inquiries through Email, Facebook, LinkedIn, Twitter, etc.

A wide selection of journals (inclusive of 9 subjects, more than 200 journals)

Providing 24-hour high-quality service

User-friendly online submission system

Fair and swift peer-review system

Efficient typesetting and proofreading procedure

Display of the result of downloads and visits, as well as the number of cited articles

Maximum dissemination of your research work

Submit your manuscript at: http://papersubmission.scirp.org/

Or contactijg@scirp.org 